Ekonomica Sharia Volume 5 Nomor 2 Edisi Februari $2020 \mid 61$

\title{
PENGARUH KAPASITAS SUMBER DAYA MANUSIA DAN PENGENDALIAN INTERN SECARA PARSIAL TERHADAP NILAI INFORMASI PELAPORAN KEUANGAN KABUPATEN/ KOTA DI PEMERINTAH PROVINSI SUMATERA SELATAN
}

\author{
Chandra Satria \\ STEBIS IGM Palembang. Email: chandras@ stebisigm.ac.id
}

\begin{abstract}
Abtsrak
Penelitian ini bertujuan untuk untuk menganalisis pengaruh kapasitas sumber daya manusia dan pengendalian intern secara parsial terhadap nilai informasi pelaporan keuangan Kabupaten/ Kota di Pemerintah Provinsi Sumatera Selatan serta menganalisis pengaruh kapasitas sumber daya manusia dan pengendalian intern secara simultan terhadap nilai informasi pelaporan keuangan Kabupaten/ Kota di Pemerintah Provinsi Sumatera Selatan. Metode penelitian yang digunakan adalah analisis statistik inferensial yaitu dengan menggunakan regresi linier berganda dengan pertimbangan bahwa data yang digunakan dalam penelitian ini merupakan data primer yang bersifat kualitatif serta metode analisis agar dapat dimengerti dan dipahami dikenal secara umum. Populasi dalam penelitian ini adalah pegawai pada bagian akuntansi/penata usahaan keuangan pada SKPD Pemerintah Kota Palembang, Kabupaten Ogan Komering Ilir dan Kabupaten Musi Banyuasin. Jumlah populasi yang digunakan dalam penelitian ini sebanyak 126 orang. Instrumen yang digunakan dalam penelitian ini adalah daftar pertanyaan (kuesioner). Pertanyaan yang diajukan kepada responden menggunakan skala Likert untuk menilai sejauh mana subjek setuju atau tidak setuju dengan pertanyaan yang diajukan. Hasil Penelitian: (1) Adanya pengaruh kapasitas sumber daya manusia yang melingkupi pendidikan, pengalaman kerja, pengetahuan, keterampilan, etika, motif berprestasi dan kesempatan berprestasi terhadap nilai informasi pelaporan keuangan Kabupaten/ Kota di Pemerintah Provinsi Sumatera Selatan, (2) Adanya pengaruh pengendalian intern yang melingkupi lingkungan pengendalian, penaksiran risiko, sistem komunikasi dan informasi akuntansi, aktivitas pengendalian dan pemantauan (monitoring) (3) Terdapat pengaruh kapasitas sumberdaya manusia dan pengendalaian intern secara bersamasama nilai informasi pelaporan keuangan Kabupaten/ Kota di Pemerintah Provinsi Sumatera Selatan. (4) Adanya variabel kapasitas sumber daya manusia memiliki pengaruh lebih dominan terhadap nilai informasi pelaporan keuangan dari pada pengendalian intern
\end{abstract}

Kata Kunci: Kapasitas Sumber Daya Manusia, Pengendalian Intern, Nilai Informasi Pelaporan Keuangan.

\section{DASAR PEMIKIRAN}

Pembangunan pada dasarnya ditujukan untuk memenuhi kebutuhan hidup masyarakat. Oleh karena itu perencanaan pembangunan harus memprioritaskan kebutuhan hidup masyarakat. Apabila dalam pelaksanaan pembangunan tersebut terjadi ketidakseimbangan antara kebutuhan masyarakat dan kebijakan pemerintah dapat menimbulkan berbagai kesenjangan yang pada akhirnya dapat menciptakan 
ketidakstabilan dalam penyelenggaraan pemerintahan itu sendiri. Berkaitan dengan kondisi di atas peran serta masyarakat harus lebih diutamakan dalam menunjang terlaksananya program pembangunan. Masyarakat sebagai agen pembangunan senantiasa mengharapkan agar pihak pemerintah memberikan perhatian yang sungguhsungguh dalam pembangunan, khususnya dalam menanggulangi korupsi, kolusi dan nepotisme $(\mathrm{KKN})$. Perhatian ini sangat penting supaya tercipta pemerintahan yang bersih dan mampu menyediakan Public Goods and Services sebagaimana diharapkan oleh masyarakat. Oleh karena itu terselenggaranya Good Governance merupakan prasyarat utama untuk mewujudkan aspirasi masyarakat dalam mencapai tujuan dan cita-cita bangsa dan negara. Berkaitan dengan hal tersebut, maka sangat diperlukan suatu kebijakan yang tepat dalam menerapkan sistem pertanggungjawaban yang akuntabel dan riil sehingga penyelenggaraan pemerintahan dapat dilakukan secara optimal.

Harus disadari bahwa terdapat banyak pihak yang mengandalkan informasi dalam laporan keuangan yang dipublikasikan oleh pemerintah daerah sebagai dasar untuk pengambilan keputusan. Oleh karena itu, informasi tersebut harus berrmanfaat bagi para pemakai. Berbicara mengenai pelaporan keuangan dan nilai informasi yang terkandung dalam laporan keuangan, pemerintah dapat menimbulkan pertanyaan "apakah pelaporan keuangan yang disajikan pemerintah selama ini sudah memenuhi kriteria kualitas informasi yang disyaratkan dalam ketentuan yang berlaku? Fenomena pelaporan keuangan pemerintah merupakan suatu hal yang menarik untuk dikaji lebih lanjut. Di dalam laporan keuangan pemerintah masih banyak disajikan data yang tidak sesuai. Selain itu juga masih banyak penyimpangan-penyimpangan yang berhasil ditemukan oleh Badan Pemeriksa Keuangan (BPK) dalam pelaksanaan audit laporan keuangan pemerintah, seperti ditunjukkan dari beberapa hasil temuan BPK (Indriasari, 2008).

Pemerintah Kota Palembang, Kabupaten Ogan Komering Ilir dan Kabupaten Musi Banyuasin, sebagaimana bagian di NKRI memiliki peran yang sangat penting dalam menciptakan pembangunan berkelanjutan, khususnya dalam bidang pemerintahan yang terkait erat dengan penduduk. Dalam melaksanakan urusan yang menjadi tanggung jawabnya, Pemerintah Kota Palembang berdasarkan Peraturan Daerah Kota Palembang Nomor 10 Tahun 2008 tentang Pelaksanaan Peraturan Daerah Kota Palembang Nomor 
Ekonomica Sharia Volume 5 Nomor 2 Edisi Februari $2020 \mid 63$

10 Tahun 2008 tentang Pembentukan, Susunan Organisasi dan Tata Kerja Lembaga Teknis Daerah Kota Palembang, memiliki 27 Lembaga Teknis Daerah dan 16 Kecamatan yang bertindak sebagai satuan kerja perangkat Daerah (SKPD).

Kemudian Kabupaten Ogan Komering Ilir berdasarkan Peraturan Daerah Kabupaten Ogan Komering Ilir Nomor 10 Tahun 2010 tentang Aparatur Dinas, memiliki 18 SKPD. Di lain pihak Kabupaten Musi Banyuasin berdasarkan Peraturan Daerah Kabupaten Musi Banyuasin Nomor 8 Tahun 2007 memiliki 20 Satuan Kerja Perangkat Daerah (SKPD) juga melaksanakan program dan kegiatan keuangan yang tidak terlepas dari penggunaan dana yang berasal dari kas negara. Pemerintah Kota Palembang, Kabupaten Ogan Komering Ilir dan Kabupaten Musi Banyuasin merupakan daerah yang sangat pesat perkembangan pembangunannya. Oleh karena itu sangat rentan terhadap pelaksanaan pertanggungjawabannya, khususnya menyangkut pertanggungjawaban keuangan negara. Disisi lain, Pemerintah Kota Palembang, Kabupaten Ogan Ilir dan Kabupaten Musi Banyuasin merupakan daerah yang telah menyelenggarakan penatausahaan keuangan sesuai dengan Peraturan Menteri Dalam Negeri Nomor 13 Tahun 2008 tentang Keuangan Daerah. Berkaitan dengan pertanggungjawaban terhadap penggunaan kas negara tersebut, maka pihak pemerintah daerah harus melaporkan dan mempertanggungjawabkannya sesuai dengan Peraturan Menteri Dalam Negeri Nomor 13 tahun 2006. Kondisi ini dapat tercapai secara optimal apabila penyelenggaraan pemerintah dilaksanakan dengan berpijak pada sistem akuntansi secara konsekuen dan berkelanjutan. Sebagai ilustrasi disajikan hasil audit laporan keuangan Pemerintah Kota Palembang, Kabupaten Ogan Ilir dan Kabupaten Musi Banyuasin dalam kurun waktu 2013 sampai dengan 2015 pada Tabel 1:

\section{Tabel 1}

Opini BPK Atas Audit Laporan Keuangan Pemerintah

\begin{tabular}{lllll} 
No. & \multicolumn{1}{c}{ Pemerintah } & Tahun 2013 & Tahun 2014 & Tahun 2015 \\
1. & $\begin{array}{l}\text { Provinsi Sumatera } \\
\text { Selatan }\end{array}$ & WTP & WTP & \\
2. & Kota Palembang & WTP & WTP & WTP \\
3. & Kab. Ogan Komering Ilir & WTP & WTP & WTP \\
4. & Kab. Ogan Ilir & WDP & WDP & WDP \\
5. & Kab. Musi Banyuasin & WTP & WTP & WTP \\
6. & Kab. Banyuasin & WTP & WTP & WTP
\end{tabular}


64

Chandra Satria, Pengaruh Kapasitas Sumber Daya Manusia dan Pengenalian Internal..

$\begin{array}{lllll}\text { 7. } & \text { Kota Prabumulih } & \text { WDP } & \text { WDP } & \text { WTP } \\ \text { 8. } & \text { Kab. Muara Enim } & \text { WDP } & \text { WDP } & \text { WDP } \\ \text { 9. } & \text { Kab. Lahat } & \text { WDP } & \text { WDP } & \text { WDP } \\ \text { 10. } & \text { Kab. Ogan Komering } & \text { TW } & \text { WDP } & \text { WDP } \\ & \text { Ulu } & & & \\ \text { 11. } & \text { Kab. OKU Timur } & \text { WDP } & \text { WDP } & \text { WDP } \\ \text { 12. } & \text { Kab. OKU Selatan } & \text { WDP } & \text { WDP } & \text { WDP } \\ \text { 13. } & \text { Kota Pagar Alam } & \text { WDP } & \text { WDP } & \text { WDP } \\ \text { 14. } & \text { Kab. Musi Rawas } & \text { WDP } & \text { WDP } & \text { WDP } \\ \text { 15. } & \text { Kab. Lubuk Linggau } & \text { WDP } & \text { WDP } & \text { WDP } \\ \text { 16. } & \text { Kab. Empat Lawang } & \text { TW } & \text { WDP } & \text { TMP }\end{array}$

Sumber: Wilkepedia Indonesia, 2016

Berdasarkan fenomena tersebut, laporan keuangan pemerintah masih belum seluruhnya memenuhi kriteria keterandalan dan ketepatwaktuan padahal laporan keuangan merupakan alat pengambilan keputusan. Laporan keuangan dikatakan berkualitas apabila memenuhi kriteria relevan dan reliabel. Laporan keuangan dikatakan memiliki nilai reliabilitas apabila mempunyai nilai prediksi atau nilai feedback dan disajikan tepat waktu. Sedangkan kriteria relevan terpenuhi jika laporan keuangan dapat diuji, netral, dan dipercaya. Oleh karena itu dalam membuat laporan keuangan diperlukan sumber daya manusia untuk menjalankan sistem yang ada. Untuk dapat menghasilkan laporan keuangan yang berkualitas, maka dibutuhkan kualitas sumber daya manusia dan sistem pengendalian intern yang baik.

Oleh karena itu, dalam mewujudkan keterandalan dan ketepatwaktuan laporan keuangan pemerintah tersebut dibutuhkan peran serta masyarakat. Masyarakat sebagai pelaku pengendalian (social control) terhadap pemerintahan sangat berperan dalam semua aktivitas pemerintah disegala bidang. Peran serta tersebut harus didasarkan pada kemampuan sumber daya manusia dan pengendalian intern yang digunakan pemerintah agar dapat membuat laporan keuangan yang andal dan tepat waktu. Dapat diartikan bahwa sebenarnya keterandalan dan ketepatwaktuan pelaporan keuangan sangat tergantung oleh sumber daya manusia karena faktor itulah yang mempengaruhi keterandalan dan ketepatwaktuan sebuah pelaporan keuangan.

\section{TINJAUAN TEORI}

James et.al (1997) menjelaskan hubungan keagenan di dalam teori agensi (agency theory) bahwa perusahaan merupakan kumpulan kontrak (nexusof contract) antara 
Ekonomica Sharia Volume 5 Nomor 2 Edisi Februari $2020 \mid 65$

pemilik sumber daya ekonomis (principal) dan manajer (agent) yang mengurus penggunaan dan pengendalian sumber daya tersebut.

Menurut Florachis (2009) penerapan manajemen risiko dapat menurunkan biaya keagenan dan meningkatkan nilai perusahaan. Manajemen risiko perusahaan juga dapat dijadikan mekanisme pengawasan dalam menurut informasi asimetris dan berkontribusi untuk menghindari perilaku oportunis dari manajer. Dalam kaitannya dengan masalah keagenan ini, positif accounting theory (Watts dan Zimmerman, 1986) mengajukan tiga hipotesis, yaitu bonus plan, hypothesis, debt/equity hypothesis, dan political cost hypothesis, yang secara implisit mengakui tiga bentuk keagenan, yaitu antara pemilik dengan manajeme, antara kreditor dengan manajemen, dan antara pemerintah dengan manajemen. Sehingga secara luas, principal bukan hanya pemilik perusahaan, tetapi juga bisa berupa pemegang saham, kreditur, maupun pemerintah.

Selanjutnya Menurut Zainum (2011:39) sumber daya manusia menempati kedudukan yang lebih tinggi dan merupakan faktor yang sangat menentukan untuk tingkat keberhasilan dan kegagalan suatu organisasi. Adapun beberapa aktivitas pokok sumber daya manusia adalah sebagai berikut:

1. Perencanaan dan analisis sumber daya manusia. Melalui perencanaan sumber daya manusia, pimpinan berusaha mengantisipasi kekuatan yang akan mempengaruhi persediaan dan tuntutan karyawan di masa depan.

2. Peluang pekerjaan yang sama. Pemenuhan hukum dan peraturan tentang kesetaraan kesempatan kerja mempengaruhi aktivitas sumber daya manusia yang lain dan integral dengan manajemen sumber daya manusia.

3. Pengangkatan karyawan. Tujuan pengangkatan karyawan adalah memberi persediaan memadai atas individu yang berkualifikasi untuk mengisi lowongan pekerjaan di organisasi.

4. Pengembangan sumber daya manusia. Dimulai dengan orientasi karyawan baru, pengembangan sumber daya manusia juga meliputi pelatihan keterampilan pekerjaan. Ketika pekerjaan berkembang dan berubah, diperlukan pelatihan ulang yang dilakukan terus menerus untuk menyesuaikan perubahan teknologi. 
$66 \mid$

Chandra Satria, Pengaruh Kapasitas Sumber Daya Manusia dan Pengenalian Internal

5. Kompensasi dan tunjangan. Kompensasi memberi penghargaan kepada karyawan atas pelaksanaan pekerjaan melalui gaji, insentif, dan tunjangan.

6. Kesehatan, keselamatan dan keamanan. Jaminan atas kesehatan fisik dan mental serta keselamatan karyawan adalah sangat penting. Program peningkatan kesehatan menaikan gaya hidup karyawan yang sehat lebih meluas. Keamanan tempat kerja menjadi lebih penting, sebagai akibat jumlah tindak kekerasan yang meningkat ditempat kerja.

7. Hubungan karyawan dan karyawan/manajemen. Hubungan antar pimpinan dan karyawan harus ditangani secara efektif apabila karyawan organisasi ingin sukses.

Sistem Pengendalian Intern Pemerintah bekerja secara otomatis melakukan fungsi pengawasan, maka setiap insan birokrasi pemerintah suka tidak suka akan bekerja "under control". Selanjutnya, apabila kondisi ini dipertahankan maka terciptalah internal control culture, artinya sistem pengendalian intern menjadi bagian dari budaya organisasi pemerintahan di Indonesia, pada tanggal 28 Agustus 2008 terbitlah PP 60/2008 tentang Sistem Pengendalian Intern Pemerintah (SPIP), diterbitkan oleh Pemerintah untuk menjawab tantangan birokrasi pemerintahan di Indonesia. Peraturan Pemerintah ini adalah penjabaran pasal 58 ayat (1) dan ayat (2) UU nomor 1 tahun 2004 tentang Perbendaharaan Negara, yakni Presiden selaku Kepala Pemerintahan mengatur dan menyelenggarakan sistem pengendalian intern di lingkungan pemerintahan secara menyeluruh.

Spirit yang mendasari Peraturan Pemerintah ini diadopsi dari pengertian pengendalian intern menurut Committee of Sponsoring Organizations of the Treadway Commission (COSO) yang merincikan pengendalian intern ke dalam 5 unsur yakni lingkungan pengendalian, penilaian risiko, kegiatan pengendalian, informasi dan komunikasi serta pemantauan/monitoring. Satu hal yang menarik dalam konsep pengendalian intern menurut COSO ini adalah munculnya soft control yaitu aspek si pelaku sistem yang tercermin dalam komponen lingkungan pengendalian, antara lain integritas dan nilai etika, filosofis manajemen dan gaya operasi. Dalam pasal 5 Peraturan Pemerintah ini, disebutkan penerapan integritas dan nilai etika perlu diterapkan suatu aturan perilaku yang berisi praktik yang dapat diterima dan praktik yang tidak dapat diterima termasuk benturan kepentingan. 
Peraturan Pemerintah Nomor 60 tahun 2008 ini adalah langkah konkrit untuk membentuk built in control artinya pengawasan by system. Siapapun pemegang amanah birokrasi pemerintahan, maka dengan sendirinya sistem yang akan melakukan pengawasan guna mencapai visi, misi dan tujuan organisasi dalam arti sempit dan mencapai visi, misi dan tujuan bernegara dalam arti seluas-luasnya sebagaimana termaktub dalam Pembukaan UUD 1945, antara lain untuk memajukan kesejahteraan umum dan mencerdaskan kehidupan bangsa, dan seterusnya. Ketika internal control system yang dijabarkan dalam SPIP bekerja secara otomatis melakukan fungsi pengawasan, maka setiap insan birokrasi pemerintah suka tidak suka akan bekerja "under control". Selanjutnya, apabila kondisi ini dipertahankan maka terciptalah internal control culture, artinya sistem pengendalian intern menjadi bagian dari budaya organisasi pemerintahan di Indonesia.

Unsur-unsur yang ada dalam Sistem Pengendalian Intern Pemerintah, yaitu:

1. Lingkungan pengendalian

PP Nomor 60/2008 mewajibkan Pimpinan Instansi Pemerintah untuk menciptakan dan memelihara lingkungan pengendalian yang menimbulkan perilaku positif dan kondusif untuk penerapan Sistem Pengendalian Intern dalam lingkungan kerjanya. Hal ini merupakan komponen yang sangat penting dan menjadi unsur dasar di dalam SPIP. Kemampuan pimpinan untuk menciptakan dan memelihara lingkungan kerja yang kondusif akan menjadi motivasi kuat bagi para pegawai untuk memberikan yang terbaik dalam pelaksanaan pekerjaannya. Sebaliknya, pimpinan yang tidak/kurang kompeten dalam menciptakan lingkungan yang positif akan berpotensi mempengaruhi pegawai untuk melakukan hal-hal negatif yang dapat merugikan instansinya.

\section{Penilaian risiko}

Penilaian risiko merupakan suatu proses pengidentifikasian dan penganalisaan risiko-risiko yang relevan dalam rangka pencapaian tujuan entitas dan penentuan reaksi yang tepat terhadap risiko yang timbul akibat perubahan (Djasoerah:2010). Ini berarti bahwa penilaian risiko dimulai dari penetapan tujuan dan berakhir dengan penentuan reaksi terhadap risiko. 
3. Kegiatan pengendalian;

Pimpinan Instansi Pemerintah wajib menyelenggarakan kegiatan pengendalian sesuai dengan ukuran, kompleksitas, dan sifat dari tugas dan fungsi Instansi Pemerintah yang bersangkutan. Yang dimaksud dengan "kegiatan pengendalian" adalah tindakan yang diperlukan untuk mengatasi risiko serta penetapan dan pelaksanaan kebijakan dan prosedur untuk memastikan bahwa tindakan mengatasi risiko telah dilaksanakan secara efektif

4. Informasi dan komunikasi;

Informasi yang ada di dalam organisasi diidentifikasi, dicatat dan dikomunikasikan dalam bentuk dan waktu yang tepat dengan cara yang efektif. Ini dilaksanakan mulai dari pimpinan hingga ke seluruh pegawai yang ada di instansi pemerintah. Dengan mengkomunikasikan informasi secara efektif, maka akan tercipta pengertian yang sama di seluruh tingkat organisasi. Ini akan menghindarkan terjadinya kesalahpahaman (misunderstanding) maupun distorsi informasi sehingga pelaksanaan tugas dan fungsi organisasi akan efektif untuk mencapai tujuan yang telah ditetapkan.

5. Pemantauan pengendalian intern.

Untuk memastikan apakah SPIP dijalankan dengan baik oleh suatu instansi pemerintah, maka perlu dilakukan pemantauan. Pemantauan akan menilai kualitas kinerja dari waktu ke waktu dan memastikan bahwa rekomendasi hasil audit dan reviu lainnya dapat segera ditindaklanjuti.

\section{PENELITIAN TERDAHULU}

Penelitian sebelumnya mengenai sumber daya manusia yang ada di instansi pemerintah disajikan pada sebagai berikut:

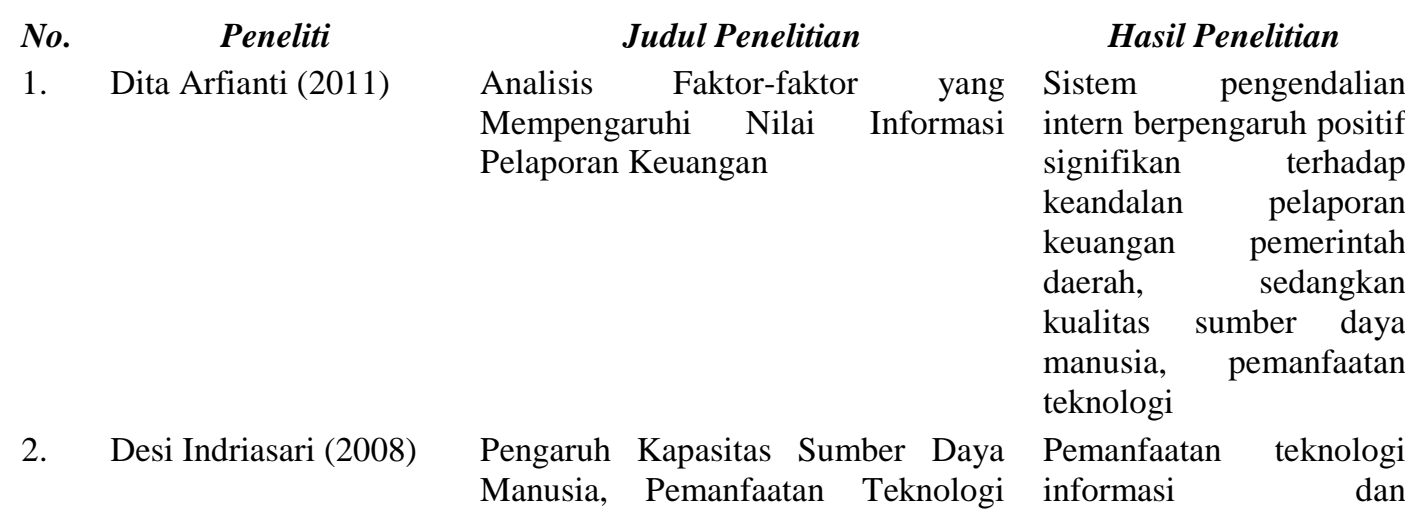


3. Celviana

Winidyaningrum (2010)

\section{Dinata (2004)}

5. Alimbudiono (2004)
Informasi, dan Pengendalian Intern Akuntansi Terhadap Nilai Informasi Pelaporan Keuangan

Pengaruh sumber daya manusia dan Pemanfaatan Teknologi Informasi Terhadap Keterandalan dan Ketepatwaktuan Nilai Informasi Pelaporan Keuangan Pemerintah Daerah Dengan Variabel Intervening Pengendalian Intern Akuntansi

Tinjauan Atas Kesiapan SDM pada Instansi Pemerintah Kota Palembang Dalam Penerapan Akuntansi Daerah Menuju Terciptanya Good Governance di Era Otonomi Daerah

Kesiapan Sumber Daya Manusia SubBagian Akuntansi Pemerintah Daerah XYZ dan Kaitannya dengan Pertanggungjawaban Keuangan Daerah Kepada Masyarakat

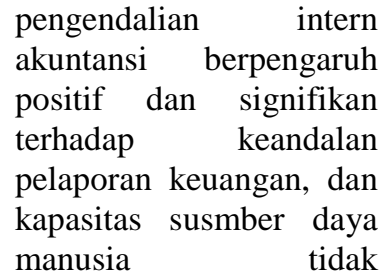

berpengaruh. Disamping itu sumber daya manusia dan pemanfaatan teknologi informasi berpengaruh positif signifikan terhadap ketepatwaktuan pelaporan keuangan pemerintah daerah

Menunjukkan pengaruh positif dari sumber daya manusia dan informasi pemanfaatan teknologi untuk pelaporan keuangan melalui keandalan akuntansi pengendalian internal. Sedangkan hasil penelitian dalam model kedua dengan uji regresi tidak menunjukkan pengaruh yang signifikan dari sumber daya manusia dan informasi pemanfaatan teknologi untuk pelaporan

Menemukan bukti empiris bahwa secara garis besar sumber daya manusia yang ada di instansi pemerintahan Kota Palembang belum sepenuhnya dinyatakan siap atas berlakunya sistem akuntansi keuangan daerah yang berdasarkan Keputusan Menteri Dalam Negeri Nomor 29 Tahun 2002

Memberikan temuan empiris bahwa pegawai berlatar belakang pendidikan akuntansi di subbagian akuntansi pemerintah XYZ masih minim, job descriptionnya belum jelas, dan 
6. Dita Ismariza (2009)

Pengaruh Kualitas Sumber Daya Manusia dan Pengendalian Intern Terhadap Nilai Informasi Pelaporan Keuanga Pemerintah Daerah.

Pengaruh Unsur-unsur Struktur Pengendalian Intern dan Lingkup Audit Terhadap Kinerja Akuntan Publik di Era Otonomi Daerah.

Kontribusi unsur-unsur Struktur Pengendalian Intern Terhadap Lingkup Audit Akuntan Publik di Kota Semarang pelatihan-pelatihan untuk menjamin fungsi akuntansi berjalan deengan baik belum dilaksanakan

Kualitas Sumber Daya Manusia dan

Pengendalian Intern

Berpengaruh Secara Signifikan Terhadap Nilai Informasi Pelaporan Keuangan pada Pemerintah Daerah.

Unsur-unsur struktur pengendalian intern berpengaruh secara parsial maupun simultan terhadap lingkup audit auntan publik di era otonomi daerah.

Unsur-unsur struktur pengendalian intern memberikan kontribusi terhadap penentuan lingkup audit akuntan publik di Kota Semarang.

\section{KERANGKA BERPIKIR}

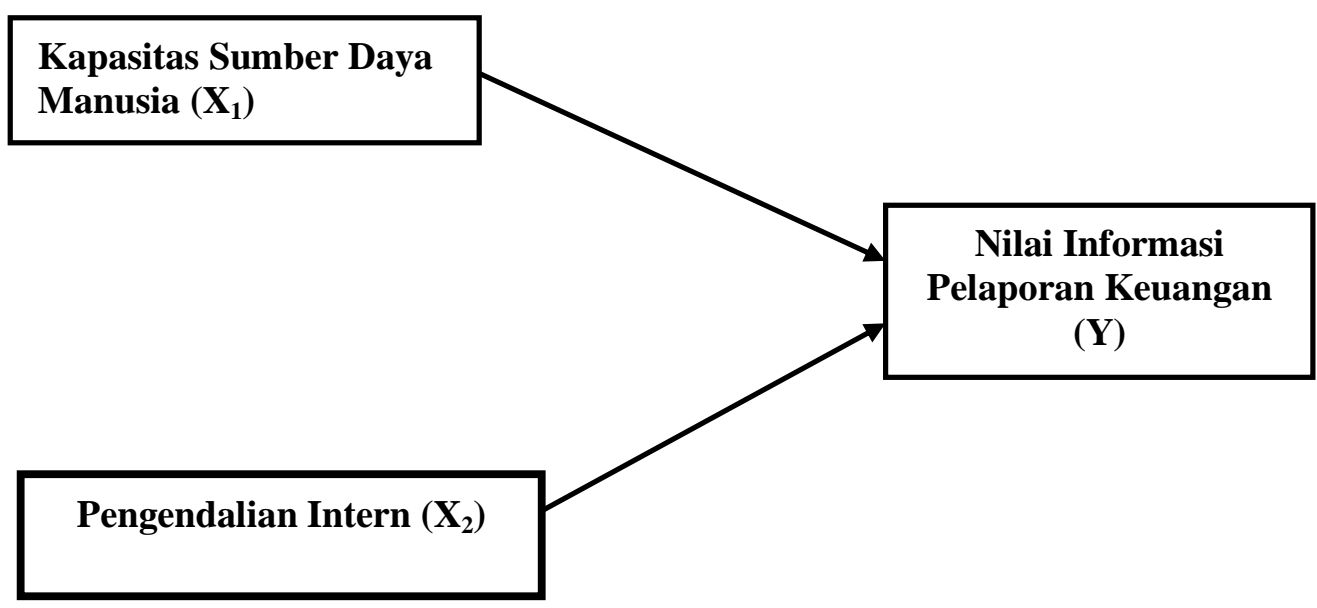

\section{Gambar 1}

Paradigma Konseptual Penelitian Pengaruh Kapasitas Sumber Daya Manusia dan Pengendalian Intern Terhadap Nilai Informasi Pelaporan Keuangan Kabupaten/ Kota di Pemerintah 


\section{METODE PENELITIAN}

Penelitian ini dilakukan di seluruh Satuan Kerja Perangkat Daerah pada Pemerintah Daerah Kota Palembang, Kabupaten Ogan Komering Ilir, dan Kabaupaten Musi Banyuasin Provinsi Sumatera Selatan. Penelitian ini dibatasi pada pengaruh kapasitas Sumber Daya Manusia dan Pengendalian Intern terhadap nilai informasi pelaporan keuangan pada Pemerintah Daearah Kota Palembang, Kabupaten Ogan Komering Ilir dan Kabupaten Musi Banyuasin Provinsi Sumatera Selatan.

\section{Populasi dan Sampel}

Populasi dalam penelitian ini adalah pegawai pada bagian akuntansi/penatausahaan keuangan pada SKPD Pemerintah Kota Palembang, Kabupaten Ogan Komering Ilir dan Kabupaten Musi Banyuasin. Jumlah populasi yang digunakan dalam penelitian ini sebanyak 126 orang.

\section{Jenis Data dan Sumber Data}

Jenis data yang digunakan oleh penulis pada penelitian ini adalah data primer dan data sekunder. Data primer dikumpulkan secara langsung dari objek penelitian. Data yang digunakan menyangkut kapasitas sumber daya manusia dan pengendalian intern serta nilai informasi pelaporan keuangan pada Pemerintah Daerah Kota Palembang, Kabupaten Ogan Komering Ilir dan Kabupaten Musi Banyuasin Provinsi Sumatera Selatan. Sementara itu data sekunder adalah telah diolah dan diperoleh dari objek penelitian, berkaitan dengan struktur organisasi perusahaan dan yang berkaitan dengan penelitian.

\section{Metode Pengumpulan Data}

Data primer dikumpulkan dengan menggunakan media berupa daftar pertanyaan (Kuesioner). Sementara itu untuk mengumpulkan data sekunder dilakukan dengan menggali informasi baik dari literatur, penelitian terdahulu yang ada kaitannya, dan data yang dapat melengkapi baik dari satuan kerja perangkat daerah (SKPD). 


\section{HASIL DAN PEMBAHASAN}

\section{A. Analisis Deskriptif}

\section{Distribusi Frekuensi Jenis Kelamin Responden}

Data yang diperoleh melalui penyebaran kuesioner kepada 60 responden penelitian yaitu 20 responden untuk tiap kabupaten/kota. Kemudian diolah dengan menggunakan program SPSS for Windows sebagai ilustrasi disajikan pada Tabel 4 berikut ini:

\section{Tabel 4. Jenis Kelamin Responden}

\section{Jenis Kelamin}

Laki-laki

perempuan

Total

Sumber : Diolah dari lampiran 1

\section{Frekuensi}

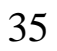

25

60

\section{Persentase}

$58,33 \%$

$41,67 \%$

$100 \%$

Berdasarkan Tabel 4 tersebut diketahui bahwa sebagian besar aparatur Pemerintah Daerah Kota Palembang, Kabupaten Ogan Komering Ilir dan Kabupaten Musi Banyuasin yang dijadikan responden adalah laki-laki sebanyak 35 orang dengan persentase sebesar $58,35 \%$, sedangkan perempuan sebanyak 25 orang dengan persentase 41,67\%. Berdasarkan jumlah ini dapat dikatakan bahwa aparatur pemerintah yang dijadikan responden di dominasi oleh kaum laki-laki. Jumlah ini diharapkan dapat mewakili aparatur yang bekerja pada Kota Palembang, Kabupaten Musi Banyuasin dan Kabupaten Ogan Komering Ilir secara keseluruhan.

\section{Distribusi Frekuensi Usia Responden}

Distribusi frekuensi usia responden ini diperoleh dari pengolahan data primer, dimana dari hasil analisis yang dilakukan diketahui bahwa terdapat usia yang produktif dan memiliki integritas tinggi sebagai aparatur pada Pemerintah Daerah Kota Palembang, Kabupaten Ogan Komering Ilir dan Kabupaten Musi Banyuasin. Sebagai ilustrasi disajikan pada Tabel 5 sebagai berikut:

\section{Tabel 5. Usia Responden}

Umur

25 s.d 30 tahun

$>30$ tahun
Frekuensi

35

25

\section{Persentase}

$58,33 \%$

$41,67 \%$ 
Ekonomica Sharia Volume 5 Nomor 2 Edisi Februari $2020 \mid 73$

Total

60

$100 \%$

Sumber : Diolah dari lampiran 1

Berdasarkan Tabel 5 tersebut diketahui bahwa sebagian besar responden yang bekerja sebagai aparatur pada Pemerintah Daerah Kota Palembang, Kabupaten Ogan Komering Ilir dan Kabupaten Musi Banyuasin berusia antara 25 tahun sampai dengan 30 tahun. Hal tersebut terlihat dari jumlah responden yang berusia antara 25 tahun sampai dengan 30 tahun sebanyak 35 orang dengan persentase sebesar 58,33\%, kemudian diikuti dengan responden yang berusia di atas 30 tahun sebanyak 25 orang dengan persentase 41,67\%. Hal ini disebabkan pada usia tersebut aparatur pemerintahan pada Kota Palembang, Kabupaten Musi Banyuasin dan Kabupaten Ogan Komering Ilir cenderung memiliki tingkat produktivitas dan kinerja yang tinggi, khususnya untuk bagian keuangan dan anggaran. Kondisi ini juga akibat faktor psikologis aparatur yang masih memiliki semangat kerja yang tinggi.

\section{Distribusi Frekuensi Lamanya Bekerja Responden}

Distribusi frekuensi lamanya responden bekerja sebagai aparatur pada Pemerintah Daerah Kota Palembang, Kabupaten Ogan Komering Ilir dan Kabupaten Musi Banyuasin. Sebagai ilustrasi disajikan pada Tabel 6 berikut ini:

\section{Tabel 6. Lamanya Bekerja Responden}

\section{Lamanya Bekerja}

$\leq 1$ Tahun

> 1 Tahun s.d 3 Tahun

> 3 Tahun s.d 5 Tahun

$>5$ Tahun

Total

\section{Frekuensi}

5

10

15

30

60

\section{Persentase}

$8,33 \%$

$16,67 \%$

$25 \%$

$50 \%$

$100 \%$

Sumber : Diolah dari kuesioner penelitian

Berdasarkan Tabel 6 tersebut diketahui bahwa sebagian besar aparatur Pemerintah Daerah Kota Palembang, Kabupaten Ogan Komering Ilir dan Kabupaten Musi 
Banyuasin yang dijadikan responden penelitian adalah mereka yang telah bekerja diatas 5 tahun sebanyak 30 orang atau 50\%, bekerja antara 3 tahun sampai dengan 5 tahun sebanyak 15 orang atau $25 \%$, bekerja antara 1 tahun sampai dengan 3 tahun sebanyak 10 orang atau $16,67 \%$ dan sisanya sebanyak 5 orang atau $8,33 \%$ adalah aparatur yang telah bekerja sampai dengan 1 tahun.

\section{Distribusi Frekuensi Pendidikan Terakhir Responden}

Distribusi frekuensi pendidikan terakhir responden ini diperoleh dari pengolahan data primer, Sebagai ilustrasi disajikan pada Tabel 7 sebagai berikut:

\section{Tabel 7. Pendidikan Responden}

\section{Tingkat Pendidikan}

SLTA/ Sederajat

Diploma/ Sederajat

Sarjana (S1)

Pascasarjana (S2)

Total

\section{Frekuensi}

15

15

25

5

60

\section{Persentase}

$25 \%$

$25 \%$

$41,67 \%$

$8,33 \%$

$100 \%$

Sumber : Diolah dari kuesioner penelitian

Berdasarkan Tabel 7 tersebut diketahui bahwa sebagian besar responden yang bekerja pada Pemerintah Daerah Kota Palembang, Kabupaten Ogan Komering Ilir dan Kabupaten Musi Banyuasin merupakan lulusan SLTA sederajat sebanyak 15 orang dengan persentase sebesar $25 \%$, kemudian diikuti dengan responden dari lulusan Diploma/sederajat sebanyak 15 orang (25\%), responden lulusan Sarjana (S1) sebanyak 25 orang $(41,67 \%)$, dan sisanya responden lulusan Pascasarjana (S2) sebanyak 5 orang $(8,33 \%)$.

\section{Uji Validitas}

\section{Uji Validitas Data Kapasitas Sumber Daya Manusia}

Data yang diuji validitasnya adalah kapasitas sumber daya manusia, pengendalian intern dan nilai informasi pelaporan keuangan. Jika hasil uji tersebut dibandingkan dengan nilai $R_{\text {tabel }}$, dengan taraf nyata $(\alpha)=5 \%$ dan $\mathrm{n}=60$, yaitu 0,254 . Sedangkan menurut Alhusin (2003:341), jika $R_{\text {hitung }}>R_{\text {tabel }}$, Valid, sedangkan jika $R_{\text {hitung }}<R_{\text {tabel }}$, 
tidak Valid. Dari hasil uji validitas dengan menggunakan korelasi bivariate untuk itemitem variabel kapasitas sumber daya manusia dapat dilihat pada Tabel 8 berikut ini :

Tabel 8.

\begin{tabular}{|c|c|c|c|c|}
\hline \multicolumn{5}{|c|}{ Hasil Uji Validitas Variabel Kapasitas Sumber Daya Manusia $\left(\mathbf{X}_{1}\right)$} \\
\hline No. & Item & $\boldsymbol{R}_{\text {hitung }}$ & $R_{\text {tabel }}(\alpha=5 \%)$ & Hasil Validitas \\
\hline 1. & $\mathrm{X}_{1 \_1}$ & $0,785^{* *}$ & 0,254 & $\mathrm{R}_{\text {hitung }}>\mathrm{R}_{\text {tabel}}$, Valid \\
\hline 2. & $X_{1 \_2}$ & $0,800 * *$ & 0,254 & $\mathrm{R}_{\text {hitung }}>\mathrm{R}_{\text {tabel }}$, Valid \\
\hline 3. & $X_{1 \_} 3$ & $0,675^{* *}$ & 0,254 & $\mathrm{R}_{\text {hitung }}>\mathrm{R}_{\text {tabel }}$, Valid \\
\hline 4. & $\mathrm{X}_{1 \_} 4$ & 0,453 & 0,254 & $\mathrm{R}_{\text {hitung }}>\mathrm{R}_{\text {tabel }}$, Valid \\
\hline 5. & $\mathrm{X}_{1 \_} 5$ & $0,649 * *$ & 0,254 & $\mathrm{R}_{\text {hitung }}>\mathrm{R}_{\text {tabel }}$, Valid \\
\hline 6. & $\mathrm{X}_{1 \_} 6$ & $0,629 * *$ & 0,254 & $\mathrm{R}_{\text {hitung }}>\mathrm{R}_{\text {tabel }}$, Valid \\
\hline 7. & $X_{1 \_} 7$ & 0,455 & 0,254 & $\mathrm{R}_{\text {hitung }}>\mathrm{R}_{\text {tabel }}$, Valid \\
\hline 8. & $\mathrm{X}_{1 \_8}$ & $0,608 * *$ & 0,254 & $\mathrm{R}_{\text {hitung }}>\mathrm{R}_{\text {tabel }}$, Valid \\
\hline 9. & $\mathrm{X}_{1 \_9}$ & 0,730 & 0,254 & $\mathrm{R}_{\text {hitung }}>\mathrm{R}_{\text {tabel }}$, Valid \\
\hline 10. & $\mathrm{X}_{1 \_} 10$ & 0,738 & 0,254 & $\mathrm{R}_{\text {hitung }}>\mathrm{R}_{\text {tabel}}$, Valid \\
\hline 11. & $\mathrm{X}_{1-11}$ & 0,425 & 0,254 & $\mathrm{R}_{\text {hitung }}>\mathrm{R}_{\text {tabel }}$, Valid \\
\hline 12. & $\mathrm{X}_{1 \_} 12$ & 0,442 & 0,254 & $\mathrm{R}_{\text {hitung }}>\mathrm{R}_{\text {tabel }}$, Valid \\
\hline 13. & $\mathrm{X}_{1-13}$ & 0,730 & 0,254 & $\mathrm{R}_{\text {hitung }}>\mathrm{R}_{\text {tabel }}$, Valid \\
\hline 14. & $\mathrm{X}_{1 \_} 14$ & 0,730 & 0,254 & $\mathrm{R}_{\text {hitung }}>\mathrm{R}_{\text {tabel }}$, Valid \\
\hline 15. & $\mathrm{X}_{1 \_} 15$ & 0,738 & 0,254 & $\mathrm{R}_{\text {hitung }}>\mathrm{R}_{\text {tabel }}$, Valid \\
\hline 16. & $\mathrm{X}_{1 \_} 16$ & 0,442 & 0,254 & $\mathrm{R}_{\text {hitung }}>\mathrm{R}_{\text {tabel }}$, Valid \\
\hline 17. & $\mathrm{X}_{1-17}$ & $0,800 * *$ & 0,254 & $\mathrm{R}_{\text {hitung }}>\mathrm{R}_{\text {tabel }}$, Valid \\
\hline 18. & $\mathrm{X}_{1 \_} 18$ & $0,675^{* *}$ & 0,254 & $\mathrm{R}_{\text {hitung }}>\mathrm{R}_{\text {tabel }}$, Valid \\
\hline 19. & $\mathrm{X}_{1 \_} 19$ & 0,453 & 0,254 & $\mathrm{R}_{\text {hitung }}>\mathrm{R}_{\text {tabel }}$, Valid \\
\hline 20. & $\mathrm{X}_{1 \_20}$ & 0,730 & 0,254 & $\mathrm{R}_{\text {hitung }}>\mathrm{R}_{\text {tabel }}$, Valid \\
\hline 21. & $\mathrm{X} 1 \_21$ & 0,730 & 0,254 & $\mathrm{R}_{\text {hitung }}>\mathrm{R}_{\text {tabel }}$, Valid \\
\hline 22. & $\mathrm{X} 1 \_22$ & 0,730 & 0,254 & $\mathrm{R}_{\text {hitung }}>\mathrm{R}_{\text {tabel }}$, Valid \\
\hline 23. & $\mathrm{X} 1 \_23$ & 0,730 & 0,254 & $\mathrm{R}_{\text {hitung }}>\mathrm{R}_{\text {tabel }}$, Valid \\
\hline 24. & X1_24 & 0,730 & 0,254 & $\mathrm{R}_{\text {hitung }}>\mathrm{R}_{\text {tabel }}$, Valid \\
\hline 25. & $\mathrm{X} 1 \_25$ & 0,730 & 0,254 & $\mathrm{R}_{\text {hitung }}>\mathrm{R}_{\text {tabel }}$, Valid \\
\hline 26. & X1_26 & 0,730 & 0,254 & $\mathrm{R}_{\text {hitung }}>\mathrm{R}_{\text {tabel }}$, Valid \\
\hline 27. & X1_27 & 0,730 & 0,254 & $\mathrm{R}_{\text {hitung }}>\mathrm{R}_{\text {tabel }}$, Valid \\
\hline 28. & X1_28 & 0,730 & 0,254 & $\mathrm{R}_{\text {hitung }}>\mathrm{R}_{\text {tabel }}$, Valid \\
\hline 29. & X1_29 & 0,730 & 0,254 & $\mathrm{R}_{\text {hitung }}>\mathrm{R}_{\text {tabel }}$, Valid \\
\hline
\end{tabular}

Sumber: Diolah dari lampiran 1

Dari hasil uji validitas yang disajikan dalam Tabel 4.5 menunjukkan hasil uji validitas dari 29 item pertanyaan/pernyataan variabel kapasitas sumber daya manusia tersebut Valid pada taraf nyata $(\alpha)=5 \%$. Disimpulkan semua item pertanyaan/pernyataan yang ada pada instrumen tersebut, dapat dijadikan sebagai alat ukur yang valid dalam analisis selanjutnya. 


\section{Uji Validitas Data Pengendalian Intern $\left(\mathbf{X}_{2}\right)$}

Dari hasil uji validitas untuk item-item variabel pengendalian intern dapat dilihat pada Tabel 9 berikut ini :

Tabel 9.

No.

1. $\quad \mathrm{X}_{2} \_1$

2. $\mathrm{X}_{2} 2$

3. $\mathrm{X}_{2} 3$

4. $\quad \mathrm{X}_{2-4}$

5. $\quad \mathrm{X}_{2}{ }_{5}$

6. $\quad \mathrm{X}_{2} 6$

7. $\mathrm{X}_{2 \_} 7$

8. $\quad \mathrm{X}_{2 \_} 8$

9. $\quad \mathrm{X}_{2} \mathrm{9}$

10. $\mathrm{X}_{2-10}$

11. $\mathrm{X}_{2} 11$

12. $\mathrm{X}_{2}$ 12

13. $\mathrm{X}_{2} 13$

14. $\mathrm{X}_{2-14}$

15. $X_{2} 15$

16. $\mathrm{X}_{2}$ 16

17. $\mathrm{X}_{2 \_} 17$

18. $\mathrm{X}_{2 \_} 18$

19. $\mathrm{X}_{2} 19$

20. $\mathrm{X}_{2} 20$

21. $\mathrm{X}_{2} 21$

22. $\mathrm{X}_{2} 22$

23. $\mathrm{X}_{2} 23$

24. $\mathrm{X}_{2} 24$

25. $\mathrm{X}_{2} 25$

26. $\mathrm{X}_{2} 26$

27. $\mathrm{X}_{2 \_} 27$

28. $\mathrm{X}_{2} 28$

29. $\mathrm{X}_{2} 29$

30. $\mathrm{X}_{2 \_} 30$

31. $\mathrm{X}_{2}$ 3 31

32. $\mathrm{X}_{2}$ 32

33. $\mathrm{X}_{2} 33$

34. $\mathrm{X}_{2 \_} 34$

35. $\quad \mathrm{X}_{2}$ 35

36. $\mathrm{X}_{2 \_} 36$
Rtabel ( $\alpha=5 \%)$

\section{Rhitung}

$0,972 * *$

$0,906 * *$

$0,929 * *$

$0,954 * *$

$0,973 * *$

$0,956 * *$

$0,896 * *$

0,544

$0,785 * *$

$0,800 * *$

$0,675 * *$

0,453

$0,649 * *$

$0,629 * *$

0,455

$0,608 * *$

0,730

0,738

0,425

0,442

0,730

0,730

0,738

0,442

0,453

0,730

0,738

0,425

0,442

0,730

0,738

0,442

0,800 **

$0,675^{* *}$

0,453

0,800 **
0,254

0,254

0,254

0,254

0,254

0,254

0,254

0,254

0,254

0,254

0,254

0,254

0,254

0,254

0,254

0,254

0,254

0,254

0,254

0,254

0,254

0,254

0,254

0,254

0,254

0,254

0,254

0,254

0,254

0,254

0,254

0,254

0,254

0,254

0,254

0,254

\section{$\left(\mathrm{X}_{2}\right)$}

Hasil Validitas

$\mathrm{R}_{\text {hitung }}>\mathrm{R}_{\text {tabel, }}$, Valid

$\mathrm{R}_{\text {hitung }}>\mathrm{R}_{\text {tabe }}$, Valid

$\mathrm{R}_{\text {hitung }}>\mathrm{R}_{\text {tabel }}$, Valid

$\mathrm{R}_{\text {hitung }}>\mathrm{R}_{\text {tabel}}$, Valid

$\mathrm{R}_{\text {hitung }}>\mathrm{R}_{\text {tabel }}$, Valid

$R_{\text {hitung }}>R_{\text {tabel}}$, Valid

$\mathrm{R}_{\text {hitung }}>\mathrm{R}_{\text {tabel}}$, Valid

$\mathrm{R}_{\text {hitung }}>\mathrm{R}_{\text {tabel}}$, Valid

$R_{\text {hitung }}>R_{\text {tabel }}$, Valid

$\mathrm{R}_{\text {hitung }}>\mathrm{R}_{\text {tabe }}$, Valid

$\mathrm{R}_{\text {hitung }}>\mathrm{R}_{\text {tabel}}$, Valid

$\mathrm{R}_{\text {hitung }}>\mathrm{R}_{\text {tabel }}$, Valid

$R_{\text {hitung }}>R_{\text {tabel }}$, Valid

$R_{\text {hitung }}>R_{\text {tabel }}$, Valid

$\mathrm{R}_{\text {hitung }}>\mathrm{R}_{\text {tabel}}$, Valid

$R_{\text {hitung }}>R_{\text {tabel }}$, Valid

$\mathrm{R}_{\text {hitung }}>\mathrm{R}_{\text {tabel }}$, Valid

$\mathrm{R}_{\text {hitung }}>\mathrm{R}_{\text {tabe }}$ l, Valid

$R_{\text {hitung }}>R_{\text {tabel }}$, Valid

$\mathrm{R}_{\text {hitung }}>\mathrm{R}_{\text {tabel}}$, Valid

$\mathrm{R}_{\text {hitung }}>\mathrm{R}_{\text {tabel }}$, Valid

$\mathrm{R}_{\text {hitung }}>\mathrm{R}_{\text {tabel}}$, Valid

$\mathrm{R}_{\text {hitung }}>\mathrm{R}_{\text {tabel}}$, Valid

$\mathrm{R}_{\text {hitung }}>\mathrm{R}_{\text {tabel }}$, Valid

$R_{\text {hitung }}>R_{\text {tabel }}$, Valid

$\mathrm{R}_{\text {hitung }}>\mathrm{R}_{\text {tabe }}$, Valid

$\mathrm{R}_{\text {hitung }}>\mathrm{R}_{\text {tabel}}$, Valid

$\mathrm{R}_{\text {hitung }}>\mathrm{R}_{\text {tabel}}$, Valid

$R_{\text {hitung }}>R_{\text {tabel }}$, Valid

$R_{\text {hitung }}>R_{\text {tabel }}$, Valid

$\mathrm{R}_{\text {hitung }}>\mathrm{R}_{\text {tabell }}$, Valid

$R_{\text {hitung }}>R_{\text {tabel }}$, Valid

$\mathrm{R}_{\text {hitung }}>\mathrm{R}_{\text {tabel }}$, Valid

$\mathrm{R}_{\text {hitung }}>\mathrm{R}_{\text {tabel}}$, Valid

$R_{\text {hitung }}>R_{\text {tabel }}$, Valid

$\mathrm{R}_{\text {hitung }}>\mathrm{R}_{\text {tabel}}$, Valid 

37.
$\mathrm{X}_{2 \_} 37$
$0,675^{* *}$
0,254
$\mathrm{R}_{\text {hitung }}>\mathrm{R}_{\text {tabel }}$, Valid

Sumber : Diolah dari kuesioner penelitian

Berdasarkan hasil uji validitas yang disajikan dalam Tabel 4.6 menunjukkan hasil uji validitas dari 37 item pertanyaan/pernyataan variabel pengendalian intern tersebut valid pada taraf nyata $(\alpha)=5 \%$. Disimpulkan bahwa semua item pertanyaan/pernyataan yang ada pada instrumen tersebut, dapat dijadikan sebagai alat ukur yang valid dalam analisis selanjutnya.

\section{Uji Validitas Nilai Informasi Pelaporan Keuangan (Y)}

Dari hasil uji validitas untuk item-item variabel nilai informasi pelaporan keuangan dapat dilihat pada Tabel 10 berikut ini :

\section{Tabel 10.}

\begin{tabular}{|c|c|c|c|c|}
\hline \multicolumn{5}{|c|}{ Hasil Uji Validitas Variabel Nilai Informasi Pelaporan Keuangan (Y) } \\
\hline No. & Item & Rhitung & Rtabel $(\alpha=5 \%)$ & Hasil Validitas \\
\hline 1. & $Y_{-} 1$ & $0,922 * *$ & 0,254 & $\mathrm{R}_{\text {hitung }}>\mathrm{R}_{\text {tabel}}$, Valid \\
\hline 2. & Y_2 & $0,961 * *$ & 0,254 & $\mathrm{R}_{\text {hitung }}>\mathrm{R}_{\text {tabel}}$, Valid \\
\hline 3. & Y_3 & $0,959 * *$ & 0,254 & $\mathrm{R}_{\text {hitung }}>\mathrm{R}_{\text {tabel }}$, Valid \\
\hline 4. & Y_4 & $0,964 * *$ & 0,254 & $\mathrm{R}_{\text {hitung }}>\mathrm{R}_{\text {tabel}}$, Valid \\
\hline 5. & Y_5 & $0,963 * *$ & 0,254 & $\mathrm{R}_{\text {hitung }}>\mathrm{R}_{\text {tabel }}$, Valid \\
\hline 6. & Y_6 & $0,966 * *$ & 0,254 & $\mathrm{R}_{\text {hitung }}>\mathrm{R}_{\text {tabel }}$, Valid \\
\hline 7. & $Y_{-} 7$ & $0,896 * *$ & 0,254 & $\mathrm{R}_{\text {hitung }}>\mathrm{R}_{\text {tabel }}$, Valid \\
\hline 8. & Y_8 & 0,447 & 0,254 & $\mathrm{R}_{\text {hitung }}>\mathrm{R}_{\text {tabel}}$, Valid \\
\hline 9. & Y_9 & $0,959 * *$ & 0,254 & $\mathrm{R}_{\text {hitung }}>\mathrm{R}_{\text {tabel }}$, Valid \\
\hline 10. & Y_10 & $0,659 * *$ & 0,254 & $\mathrm{R}_{\text {hitung }}>\mathrm{R}_{\text {tabel }}$, Valid \\
\hline
\end{tabular}

Sumber : Dolah dari kuesioner penelitian

Dari hasil hasil uji validitas dari 10 item pertanyaan/pernyataan variabel nilai informasi pelaporan keuangan yang disajikan dalam Tabel 4.7 tersebut valid pada taraf nyata $(\alpha)=5 \%$. Disimpulkan semua item pertanyaan/pernyataan yang ada pada instrumen tersebut, dapat dijadikan sebagai alat ukur yang valid dalam analisis selanjutnya.

\section{Uji Reliabilitas}

\section{Uji Reliabilitas Data Variabel Kapasitas Sumber Daya Manusia $\left(X_{1}\right)$}

Dalam melakukan pengujian reliabilitas terhadap item-item pernyataan/pertanyaan variabel kapasitas sumber daya manusia, pengendalian intern dan nilai infromasi pelaporan keuangan pemerintah daerah, penulis menggunakan metode Alpha Cronbach. 
Hasil uji reliabilitas dengan menggunakan Alpha Cronbach's untuk item-item variabel kapasitas sumber daya manusia dapat dilihat pada Tabel 11 berikut ini.

Tabel 11.

Hasil Uji Reliabilitas Item-item Kapasitas Sumber Daya Manusia

\begin{tabular}{|c|c|c|c|}
\hline No. & Item & Cronbach's Alpha Item & Cronbach's Alpha \\
\hline 1. & $\mathrm{X}_{1 \_1}$ & 0,614 & 0,599 \\
\hline 2. & $\mathrm{X}_{1 \_2}$ & 0,624 & 0,599 \\
\hline 3. & $\mathrm{X}_{1 \_3}$ & 0,650 & 0,599 \\
\hline 4. & $X_{1 \_} 4$ & 0,716 & 0,599 \\
\hline 5. & $\mathrm{X}_{1 \_5}$ & 0,655 & 0,599 \\
\hline 6. & $\mathrm{X}_{1 \_6}$ & 0,658 & 0,599 \\
\hline 7. & $\mathrm{X}_{1 \_7}$ & 0,707 & 0,599 \\
\hline 8. & $\mathrm{X}_{1 \_8}$ & 0,665 & 0,599 \\
\hline 9. & $\mathrm{X}_{1 \_9}$ & 0,725 & 0,599 \\
\hline 10. & $\mathrm{X}_{1 \_} 10$ & 0,707 & 0,599 \\
\hline 11. & $\mathrm{X}_{1-11}$ & 0,614 & 0,599 \\
\hline 12. & $\mathrm{X}_{1 \_} 12$ & 0,624 & 0,599 \\
\hline 13. & $\mathrm{X}_{1 \_} 13$ & 0,650 & 0,599 \\
\hline 14. & $\mathrm{X}_{1 \_} 14$ & 0,716 & 0,599 \\
\hline 15. & $\mathrm{X}_{1 \_} 15$ & 0,655 & 0,599 \\
\hline 16. & $\mathrm{X}_{1 \_16}$ & 0,658 & 0,599 \\
\hline 17. & $\mathrm{X}_{1 \_} 17$ & 0,707 & 0,599 \\
\hline 18. & $\mathrm{X}_{1 \_} 18$ & 0,665 & 0,599 \\
\hline 19. & $\mathrm{X}_{1 \_19}$ & 0,725 & 0,599 \\
\hline 20. & $X_{1 \_} 20$ & 0,707 & 0,599 \\
\hline 21. & $X_{1 \_} 21$ & 0,707 & 0,599 \\
\hline 22. & $X_{1 \_} 22$ & 0,665 & 0,599 \\
\hline 23. & $X_{1 \_23}$ & 0,725 & 0,599 \\
\hline 24. & $X_{1 \_} 24$ & 0,707 & 0,599 \\
\hline 25. & $X_{1 \_} 25$ & 0,614 & 0,599 \\
\hline 26. & $X_{1 \_} 26$ & 0,624 & 0,599 \\
\hline 27. & $X_{1 \_27}$ & 0,650 & 0,599 \\
\hline 28. & $\mathrm{X}_{1 \_28}$ & 0,716 & 0,599 \\
\hline 29. & $X_{1 \_} 29$ & 0,655 & 0,599 \\
\hline
\end{tabular}

Sumber : Diolah dari kuesioner penelitian

Berdasarkan Tabel 11 di atas, dapat dilihat bahwa semua item-item variabel kapasitas sumber daya manusia tersebut reliabel jika dibandingkan dengan nilai Cronbach's Alphanya, sehingga item-item tersebut dapat dijadikan alat ukur dalam analisis selanjutnya. 
Ekonomica Sharia Volume 5 Nomor 2 Edisi Februari 2020 79

\section{Uji Reliabilitas Variabel Pengendalian Intern $\left(\mathbf{X}_{2}\right)$}

Hasil uji Reliabilitas dengan menggunakan Alpha Cronbach's untuk item-item variabel pengendalian intern dapat dilihat pada Tabel 12 berikut ini:

Tabel 12.

\section{Hasil Uji Reliabilitas Item-item Pengendalian Intern $\left(\mathbf{X}_{2}\right)$}

No.

1.

2.

3. $\mathrm{X}_{2} 3$

4. $\quad \mathrm{X}_{2} 4$

5. $\quad \mathrm{X}_{2} 5$

6. $\quad \mathrm{X}_{2} 6$

7. $\quad \mathrm{X}_{2} 7$

8. $\quad \mathrm{X}_{2} 8$

9. $\quad \mathrm{X}_{2}-9$

10. $\mathrm{X}_{2} 10$

11. $\mathrm{X}_{2} \_11$

12. $\mathrm{X}_{2} 12$

13. $\mathrm{X}_{2} \_13$

14. $\mathrm{X}_{2} 14$

15. $\mathrm{X}_{2} 15$

16. $\mathrm{X}_{2} 16$

17. $\quad \mathrm{X}_{2} 17$

18. $\mathrm{X}_{2} 18$

19. $\mathrm{X}_{2} 19$

20. $\mathrm{X}_{2} 20$

21. $\mathrm{X}_{2} 21$

22. $\mathrm{X}_{2} 22$

23. $\mathrm{X}_{2} 23$

24. $\mathrm{X}_{2} 24$

25. $\quad \mathrm{X}_{2} 25$

26. $\mathrm{X}_{2} 26$

27. $\mathrm{X}_{2} 27$

28. $\quad \mathrm{X}_{2} 28$

29. $\mathrm{X}_{2} 29$

30. $\mathrm{X}_{2} 30$

31. $\mathrm{X}_{2} 31$

32. $\mathrm{X}_{2} 32$

33. $\mathrm{X}_{2} 33$

34. $\mathrm{X}_{2} 34$

35. $\quad \mathrm{X}_{2} 35$
Cronbach's Alpha Item

0,616

0,623

0,616

0,656

0,613

0,634

0,703

0,620

0,614

0,624

0,650

0,716

0,655

0,658

0,707

0,665

0,725

0,707

0,614

0,624

0,650

0,716

0,655

0,658

0,707

0,614

0,624

0,650

0,716

0,655

0,658

0,614

0,624

0,650

0,716
Cronbach's Alpha

0,536

0,536

0,536

0,536

0,536

0,536

0,536

0,536

0,536

0,536

0,536

0,536

0,536

0,536

0,536

0,536

0,536

0,536

0,536

0,536

0,536

0,536

0,536

0,536

0,536

0,536

0,536

0,536

0,536

0,536

0,536

0,536

0,536

0,536

0,536 
$80 \mid$

Chandra Satria, Pengaruh Kapasitas Sumber Daya Manusia dan Pengenalian Internal

36.

$\mathrm{X}_{2} 36$

0,655

0,536

37.

$\mathrm{X}_{2} 37$

0,707

0,536

Sumber : Diolah dari kuesioner penelitian

Berdasarkan Tabel 12 di atas, dapat dilihat bahwa semua item-item variabel pengendalian intern tersebut reliabel jika dibandingkan dengan nilai Cronbach's Alphanya, sehingga item-item tersebut dapat dijadikan alat ukur yang reliabel dalam analisis selanjutnya.

\section{Uji Reliabilitas Variabel Nilai Informasi Pelaporan Keuangan (Y)}

Hasil uji Reliabilitas dengan menggunakan Alpha Cronbach's untuk item-item variabel nilai informasi pelaporan keuangan dapat dilihat pada Tabel 13 berikut ini:

Tabel 13.

\begin{tabular}{|c|c|c|c|}
\hline \multicolumn{4}{|c|}{ Hasil Uji Reliabilitas Item-item Nilai Informasi Pelaporan Keuangan (Y) } \\
\hline No. & Item & Cronbach's Alpha Item & Cronbach's Alpha \\
\hline 1. & Y_29 & 0,616 & 0,598 \\
\hline 2. & Y_30 & 0,721 & 0,598 \\
\hline 3. & Y_31 & 0,763 & 0,598 \\
\hline 4. & Y_32 & 0,617 & 0,598 \\
\hline 5. & Y_33 & 0,616 & 0,598 \\
\hline 6. & Y_34 & 0,649 & 0,598 \\
\hline 7. & Y_35 & 0,609 & 0,598 \\
\hline 8. & Y_36 & 0,620 & 0,598 \\
\hline 9. & Y_32 & 0,657 & 0,598 \\
\hline 10. & Y_34 & 0,629 & 0,598 \\
\hline
\end{tabular}

Sumber : Diolah dari kuesioner penelitan

Berdasarkan Tabel 13 di atas, dapat dilihat bahwa semua item-item variabel nilai informasi pelaporan keuangan tersebut reliabel jika dibandingkan dengan nilai Cronbach's Alphanya, sehingga item-item tersebut dapat dijadikan alat ukur yang reliabel dalam analisis selanjutnya.

\section{Uji Normalitas}

Hasil uji normalitas untuk item-item variabel Kapasitas Sumber Daya Manusia $\left(\mathrm{X}_{1}\right)$, Pengendalian Intern $\left(\mathrm{X}_{2}\right)$ dan Nilai Informasi Pelaporan Keuangan (Y) menggunakan one-sample Kolmogorov-Smirmov Test disajikan pada Tabel 14 sebagai berikut: 
Tabel 14.

Hasil Uji Normalitas Data One-Sample Kolmogorov-Smirmov Test $\begin{array}{ccc}\text { Kapasitas } & \text { Pengendalian } & \text { Informasi } \\ \text { Sumber Daya } & \text { Intern } & \text { Pelaporan } \\ \text { Manusia } & & \text { Keuangan }\end{array}$

N

Normal Parameters ${ }^{\mathrm{a}, \mathrm{b}}$

Most Extreme

Differences

Kolmogorov-Smirmov Z

Asymp. Sig (2-tailed)

a. Test distribution is Normal

b. Calculated from data
60

Mean

Std. Deviation

Absolute

Positive

Negative
39.12

4.541

.093

.090

$-.093$

.715

.687
60

35.08

1.813

.122

.098

$-, 122$

.939

.341
60

38.00

8.219

.291

.129

1.291

2.236

.495

Sumber : Diolah dari kuesioner penelitan

Berdasarkan Tabel 14 menunjukkan bahwa variabel Kapasitas Sumber Daya Manusia $\left(\mathrm{X}_{1}\right)$, Pengendalian Intern $\left(\mathrm{X}_{2}\right)$ dan Nilai Informasi Pelaporan Keuangan $(\mathrm{Y})$, semuanya memiliki nilai yang normal, dikarenakan nilai Asymp. Sig > 0,05, yaitu nilai variabel Kapasitas Sumber Daya Manusia $\left(\mathrm{X}_{1}\right)$ 0,687, variabel Pengendalian Intern 0,341 dan Nilai Informasi Pelaporan Keuangan (Y) 0,495. Hal ini menunjukkan bahwa penyebaran frekuensi nilai sesuai dengan kaedah kurva normal.

\section{Uji Multikolineritas}

Pengujian multikolinearitas dilakukan agar variabel-variabel independen dalam penelitian tidak terjadi korelasi. Pengujian multikolinearitas dilakukan dengan melihat besarnya nilai tolerance dan variance inflation factor (VIF). Suatu data tidak mengandung multikolinearitas jika nilai VIF berada di sekitar 1 dan tolerance mendekati 1.

Berdasarkan hasil perhitungan dengan menggunakan SPSS, diperoleh nilai tolerance dan VIF dari masing-masing variabel independen pada Tabel 15 sebagai berikut:

Tabel 15.

\section{Coefficients $^{\mathrm{a}}$}

\section{Hasil Uji Multikolinearitas}

Model

1.

Kapasitas Sumber Daya Manusia

\begin{tabular}{cc}
\multicolumn{2}{c}{ Cilinearity Statistics } \\
Tolerance & VIF \\
.991 & 1.009
\end{tabular}


a. Dependent Variable: Nilai Informasi Pelaporan Keuangan

\section{Sumber : Diolah dari kuesioner penelitan}

Hasil perhitungan yang disajikan pada Tabel 15 terlihat bahwa nilai tolerance variabel Kapasitas Sumber Daya Manusia $\left(\mathrm{X}_{1}\right)$ 0,991 dan Pengendalian Intern $\left(\mathrm{X}_{2}\right)$ 0,983, sedangkan nilai VIF variabel Kapasitas Sumber Daya Manusia $\left(\mathrm{X}_{1}\right)$ 1,009 dan variabel PengendalianIntern $\left(\mathrm{X}_{2}\right)$ 1,017. Nilai tolerance dari setiap variabel independen mendekati 1 dan nilai VIF berada disekitar 1 maka dapat disimpulkan bahwa dalam penelitian ini tidak terjadi multikolinearitas.

\section{Uji Heterokedastisitas}

Pengujian heterokedastisitas dilakukan dengan melihat grafik plot antara nilai prediksi variabel terikat (ZPRED) dengan ressidualnya (SRESID). Deteksi ada tidaknya heterokedastisitas dapat dilakukan dengan melihat ada tidaknya pola tertentu pada grafik scaterrplot antara SRESID dan ZPRED dimana sumbu Y adalah residual ( $\mathrm{Y}_{\text {prediksi }}$ - $\mathrm{Y}_{\text {sesungguhnya }}$ ) yang telah diprediksi.

Jika ada pola tertentu seperti titik-titik yang membentuk pola tertentu yang teratur (bergelombang, melebar kemudian menyempit), maka mengindikasikan telah terjadi heterokedastisitas. Jika tidak ada pola yang jelas serta titik-titik menyebar di atas dan di bawah angka 0 pada sumbu Y, maka tidak terjadi heterokedastisitas atau dengan kata lain terjadi homokedastisitas. Hasil pengolahan data yang dilakukan dengan program SPSS, disajikan pada Gambar 2 : 


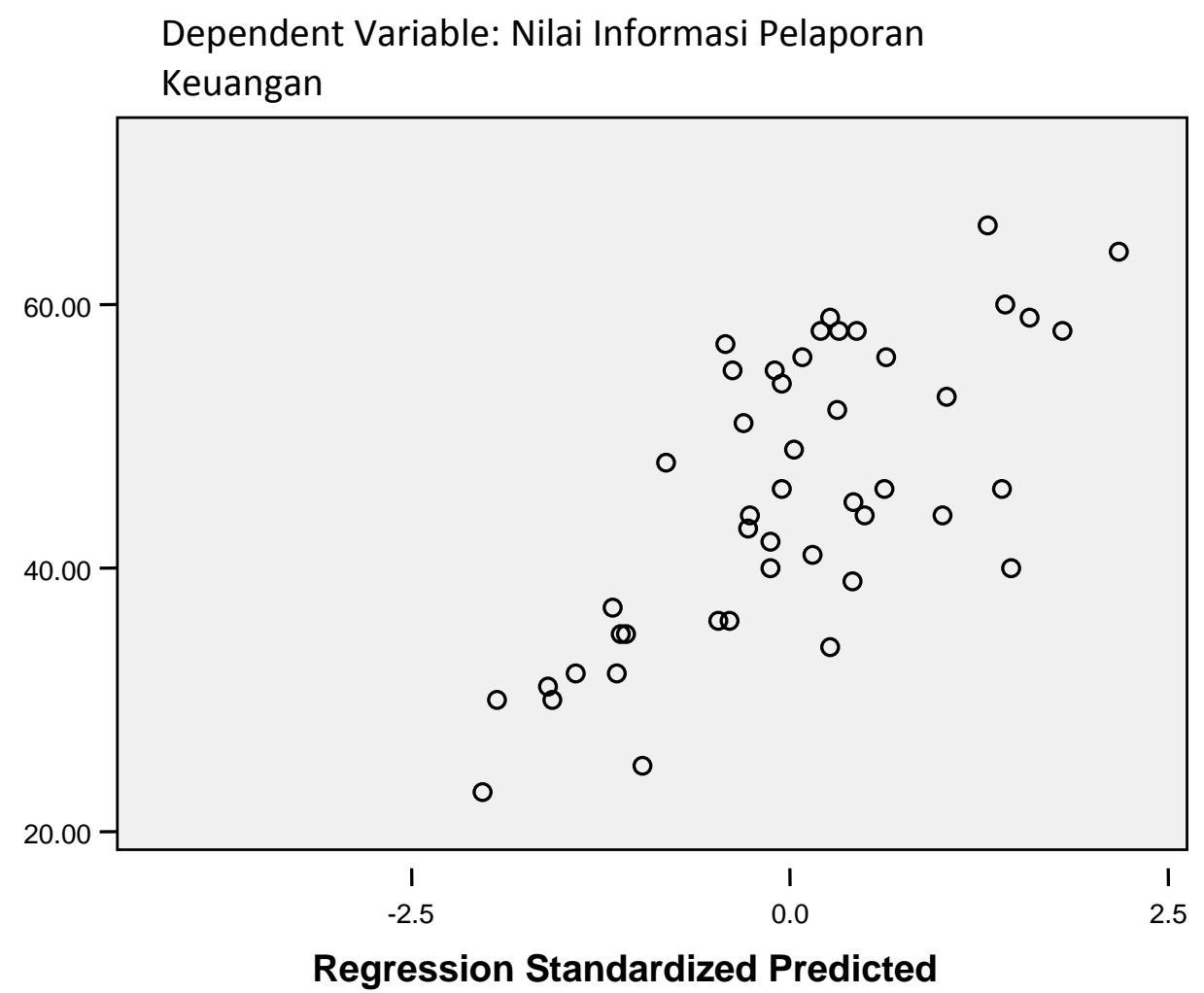

\section{Gambar 2}

\section{Scatterplot}

Berdasarkan Gambar 2 tersebut terihat bahwa titik-titik yang membentuk diagram scatterplot tersebut menyebar dan tidak membentuk pola tertentu, dengan demikian dapat disimpulkan bahwa data dalam penelitian tidak mengandung heterokedastisitas.

\section{Uji Autokorelasi}

Untuk menguji apakah suatu data mengandung autokorelasi, dapat dilihat dari besaran DW (Durbin Watson). Suatu persamaan yang tidak mengandung autokorelasi, apabila hasil nilai Durbin Watson dari persamaannya berkisar antara 1,55 sampai 2,46. Hasil autokorelasi data penelitian ini disajikan pada Tabel 16 sebagai berikut: 
Model \\ Tabel 16. Hasil Uji Autokorelasi}
$\mathbf{R}$
R Square

Adjusted

$R$ Square

Std. Error of the

Estimate

$.720^{\mathrm{a}}$

.518

.495

7.81720

Durbin-Watson

2.080

a. Predictors: (Constant): Pengendalian Intern $\left(X_{2}\right)$ dan Kapasitas Sumber Daya Manusia $\left(X_{1}\right)$

b. Dependent Variable: Nilai Informasi Pelaporan Keuangan (Y)

Melalui Tabel 16 tersebut diperoleh nilai Durbin - Watson 2,080, dengan demikian dapat disimpulkan bahwa data tersebut tidak mengandung autokorelasi. Dari penggunaan uji asumsi klasik yang telah dilakukan, maka disimpulkan bahwa data yang digunakan dalam penelitian memenuhi syarat untuk dianalisis dengan regresi.

\section{KESIMPULAN}

1. Pengaruh Parsial Kapasitas Sumber Daya Manusia $\left(\mathrm{X}_{1}\right)$ Terhadap Nilai Informasi Pelaporan Keuangan (Y)

Berdasarkan perhitungan yang telah dilakukan, besarnya pengaruh secara parsial kapasitas sumber daya manusia terhadap nilai informasi pelaporan keuangan pemerintah daerah dijelaskan melalui parameter koefisien regresi $\left(\beta_{1}\right)$. Untuk variabel kapasitas sumber daya manusia $\left(X_{1}\right)$ sebesar 0,858 karena harga $\beta_{1}$ nilainya positif maka dapat disimpulkan bahwa terdapat pengaruh positif antara kapasitas sumber daya manusia terhadap nilai informasi pelaporan keuangan pemerintah. Dengan demikian setiap kapasitas sumber daya manusia meningkat (bertambah baik) akan mengakibatkan peningkatan terhadap nilai informasi pelaporan keuangan.

Dari hasil perhitungan itu semua dapat menjelaskan bahwa koefisien determinasi $\left(\mathrm{R}^{2}\right)$ untuk variabel $\mathrm{X}_{1}$ sebesar 0,7361 berarti nilai informasi pelaporan keuangan $(\mathrm{Y})$ dapat dijelaskan oleh variabel kapasitas sumber daya manusia sebesar 73,61\%. Kapasitas sumber daya manusia yang meliputi pendidikan, pengalaman kerja, pengetahuan, keterampilan, etika, motif berprestasi serta kesempatan berprestasi merupakan aspek terpenting yang mampu menjadi pemicu untuk meningkatkan nilai informasi pelaporan keuangan. Kapasitas harus dilihat sebagai kemampuan untuk mencapai kinerja, untuk menghasilkan keluaran-keluaran (outputs) dan hasil-hasil (outcomes). 
2. Uji Parsial Pengaruh Kapasitas Sumber Daya Manusia $\left(\mathrm{X}_{1}\right)$ Terhadap Nilai Informasi Pelaporan Keuangan (Y)

Hasil uji hipotesis secara parsial pengaruh kapasitas sumber daya manusia $\left(\mathrm{X}_{1}\right)$ terhadap nilai informasi pelaporan keuangan (Y) didapat nilai t hitung sebesar 4,657 lebih besar dari nilai t tabel sebesar 1,671 untuk tingkat kesalahan 1\% dan 2,000 untuk tingkat kesalahan 5\%. Hal ini bermakna bahwa kapasitas sumber daya manusia secara parsial memiliki pengaruh terhadap nilai informasi pelaporan keuangan pemerintah daerah.

3. Pengaruh Pengendalian Intern $\left(\mathrm{X}_{2}\right)$ Terhadap Nilai Informasi Pelaporan Keuangan (Y)

Berdasarkan perhitungan pada lampiran 7 Tabel coeficients (a) terlihat bahwa parameter koefisien regresi $(\beta 2)$ untuk variabel pengendalian intern $\left(\mathrm{X}_{2}\right)$ besarnya 0,375 , karena harga $\beta_{2}$ positif maka dapat disimpulkan bahwa terdapat pengaruh positif antara variabel pengendalian intern terhadap nilai informasi pelaporan keuangan ( $\mathrm{Y}$ ) sedemikian rupa. Hasil perhitungan ini memiliki makna bahwa setiap kualitas pengendalian intern meningkat (bertambah baik) sebesar 100\% akan mengakibatkan peningkatan terhadap nilai informasi pelaporan keuangan pemerintah daerah sebesar $37,5 \%$.

Berdasarkan uraian itu juga diketahui bahwa koefisien determinasi $\left(\mathrm{R}^{2}\right)$ untuk variabel pengendalian intern $\left(\mathrm{X}_{2}\right)$ sebesar 0,1406 , berarti nilai informasi pelaporan keuangan $(\mathrm{Y})$ dapat dijelaskan oleh variabel pengendalian intern $\left(\mathrm{X}_{2}\right)$ sebesar $14,06 \%$. Hal ini bermakna bahwa pengendalian intern merupakan faktor atau sarana yang penting dalam meningkatkan nilai informasi pelaporan keuangan pemerintah daerah.

4. Uji Parsial Pengaruh Pengendalian Intern $\left(\mathrm{X}_{2}\right)$ Terhadap Nilai Informasi Pelaporan Keuangan (Y)

Berdasarkan hasil uji hipotesis variabel pengendalian intern $\left(\mathrm{X}_{2}\right)$ terhadap nilai informasi pelaporan keuangan pemerintah daerah $(\mathrm{Y})$ di dapat nilai t hitung sebesar 2,407 lebih besar dari nilai t tabel sebesar 1,671 untuk tingkat kesalahan 1\% dan 2,000 untuk tingkat kesalahan 5\%. Hal ini bermakna bahwa pengendalian intern secara parsial berpengaruh terhadap nilai informasi pelaporan keuangan pemerintah daerah. Berdasarkan hasil uji hipotesis tersebut maka hipotesis yang menyatakan kapasitas 
$86 \mid$

Chandra Satria, Pengaruh Kapasitas Sumber Daya Manusia dan Pengenalian Internal

sumber daya manusia secara parsial memiliki pengaruh terhadap nilai informasi pelaporan keuangan daerah dan pengendalian intern secara parsial memiliki pengaruh terhadap nilai informasi pelaporan keuangan pemerintah daerah diterima. Hal ini bermakna bahwa kapasitas sumber daya manusia dan pengendalian intern berpengaruh terhadap nilai informasi pelaporan keuangan pada Pemerintah Daerah Kota Palembang, Kabupaten Ogan Komering Ilir dan Kabupaten Musi Banyuasin.

5. Pengaruh Simultan Kapasitas Sumber Daya Manusia $\left(X_{1}\right)$ dan Pengendalian Intern $\left(\mathrm{X}_{2}\right)$ Terhadap Nilai Informasi Pelaporan Keuangan (Y)

Berdasarkan hasil analisis regressi berganda (multiple regression) diketahui bahwa koefisien determinasi (coeficient of determination) yang dinotasikan dengan $\mathrm{R}^{2}$ besarnya 0,518, ini berarti nilai informasi pelaporan keuangan daerah dapat dijelaskan oleh kapasitas sumber daya manusia dan pengendalian intern yang diturunkan dalam model sebesar $51,8 \%$, atau dengan kata lain pengaruh kapasitas sumber daya manusia dan pengendalian intern terhadap kinerja karyawan sebesar 51,8\%. Jadi sisanya sebesar $48,2 \%$ dijelaskan oleh variabel-variabel lain yang tidak dimasukkan dalam model penelitian ini.

Selanjutnya berdasarkan parameter koefisien regresi $(\beta)$ untuk masing-masing variabel bebas yaitu variabel kapasitas sumber daya manusia dan pengendalian intern memiliki pengaruh secara parsial sebesar 0,850 dan 0,375. Dalam bentuk persamaan dapat ditulis sebagai berikut:

$\mathrm{Y}=3.130+0,858$ Kapasitas Sumber Daya Manusia + 0,375 Pengendalian Intern.

Berdasarkan persamaan tersebut terlihat bahwa parameter koefisien regresinya $(\beta)$ untuk seluruh variabel bebas adalah positif. Hal ini menunjukkan bahwa terdapat pengaruh linier positif antara kapasitas sumber daya manusia dan pengendalian intern terhadap nilai informasi pelaporan keuangan pemerintah daerah sehingga setiap terjadi peningkatan kapasitas sumber daya manusia dan pengendalian intern maka nilai informasi pelaporan keuangan kinerja karyawan akan mengalami kenaikan dalam kualitasnya.

Hasil penelitian ini mengisyaratkan bahwa nilai informasi pelaporan keuangan pada Pemerintah Daerah Kota Palembang, Kabupaten Ogan Komering Ilir dan Kabupaten 
Musi Banyuasin ditentukan oleh kapasitas sumber daya manusia dan pengendalian intern yang memadai. Semakin tinggi kualitas kapasitas sumber daya manusia dan pengendalian intern maka semakin baik kualitas nilai informasi pelaporan keuangan. Tanpa dukungan kapasitas sumber daya manusia yang handal dan pengendalian intern yang optimal maka nilai informasi pelaporan keuangan yang dihasilkan akan sangat minim kualitasnya. Dalam pengertian bahwa nilai informasi pelaporan keuangan yang dihasilkan tidak mampu terealisasi sesuai dengan harapan.

6. Uji Simultan Pengaruh Kapasitas Sumber Daya Manusia $\left(\mathrm{X}_{1}\right)$ dan Pengendalian Intern $\left(\mathrm{X}_{2}\right)$ Terhadap Nilai Informasi Pelaporan Keuaangan (Y)

Untuk pengujian secara simultan pengaruh antara kapasitas sumber daya manusia dan pengendalian intern terhadap kinerja kayawan di dapat nilai $\mathrm{F}$ hitung sebesar 23,091 lebih besar dari nilai $\mathrm{F}$ tabel 2,76 untuk tingkat kesalahan 5\% dan 4,13 untuk tingkat kesalahan 1\%. Hal ini bermakna bahwa hipotesis yang menyatakan bahwa secara simultan kapasitas sumber daya manusia dan pengendalian intern memiliki pengaruh terhadap nilai informasi pelaporan keuangan pemerintah daerah diterima. Kondisi seperti ini mengisyaratkan bahwa kapasitas sumber daya manusia dan pengendalian intern secara bersama-sama memiliki pengaruh terhadap nilai informasi pelaporan keuangan pemerintah daerah. Besar kecilnya angka korelasi tersebut merefleksikan kuat atau lemahnya atau keeratan hubungan antar variabel.

Berdasarkan hasil pengolahan data yang telah dilakukan terhadap 60 orang responden yang bekerja pada Pemerintah Daerah Kota Palembang, Kabupaten Ogan Komering Ilir dan Kabupaten Musi Banyuasin, diperoleh nilai korelasi antara variabel kapasitas sumber daya manusia $\left(\mathrm{X}_{1}\right)$ terhadap nilai informasi pelaporan keuangan pemerintah daerah menunjukkan angka sebesar 0,673. Angka ini menunjukkan adanya korelasi yang kuat dan searah. Hal ini bermakna apabila variabel kapasitas sumber daya manusia semakin meningkat kualitasnya maka nilai informasi pelaporan keuangan pemerintah daerah yang dihasilkan juga semakin baik kualitasnya.

Selanjutnya nilai korelasi antara pengendalian intern $\left(\mathrm{X}_{2}\right)$ terhadap nilai informasi pelaporan keuangan pemerintah daerah menunjukkan angka 0,524. Angka ini juga menunjukkan adanya korelasi yang kuat antara variabel pengendalian intern $\left(\mathrm{X}_{2}\right)$ terhadap nilai informasi pelaporan keuangan pemerintah daerah (Y). Hal ini bermakna 
apabila variabel pengendalian intern $\left(\mathrm{X}_{2}\right)$ meningkat kualitasnya maka nilai informasi pelaporan keuangan yang dihasilkan semakin meningkat pula kualitasnya.

Berdasarkan uraian di atas dapat disimpulkan bahwa kapasitas sumber daya manusia dan pengendalian intern merupakan faktor yang sangat mendasar bagi tercapainya nilai informasi pelaporan keuangan yang baik dan optimal. Tanpa adanya dukungan kapasitas sumber daya manusia yang baik, pengendalian intern yang memadai maka nilai informasi pelaporan keuangan tidak akan baik (optimal).

\section{DAFTAR PUSTAKA}

Alhusin, Syahri, 2008, “Aplikasi Statistik Praktis dengan SPSS 14.0 for Windows”; PT. Gramedia Pustaka Indonesia, Jakarta.

Ambar Teguh. 2012. Memahami Good Governance dalam Perspektif Sumber Daya Manusia. Gaya media, Yogyakarta

Amin Widjaya, 2008, “Management Audit Suatu Pengantar”, Edisi kedua, PT Rineka Cipta, Jakarta.

Buchari Zainun. 2011. Manajemen dan Motivasi. Balai Aksara, Jakarta.

Dwi Priyanto. 2009. Mandiri belajar SPSS, Cetakan ketiga, PT. Buku Kita, Jakarta.

Eko Raharjo, 2013, "Teori Agensi dan Teori Stewardship Dalam Perspektif Akuntansi", www.bpk.go.id, Diakses tanggal 12 Desember 2013

Florachis, C, 2009, "Agency Cost and Corporate Governance Mechanisms: Evidence for UK Firms, ” International Journal of Managerial Finance, Volume 4. No. 1 PP. 37-59

Irfan Fathoni, 20000, "Kontribusi Unsur-unsur Struktur Pengendalian Intern Terhadap Penentuan Lingkup Audit Akuntan Publik Di Kota Semarang”, Tesis Program Pascasarjana BKU Ilmu Ekonomi dan Akuntansi Universitas Padjajaran, Bandung.

Iwan Triyuwono \& Roekhudin. 2000. Konsistensi Praktik Sistem Pengendalian Intern dan Akuntabilitas pada Lazis (studi kasus di Lazis X Jakarta). Jual Riset Akuntansi Indonesia. Vo. 3 No. 2 Hal. 151-167.

Jakfarudin, Kms, 2001, "Pengaruh Unsur-Unsur Struktur Pengendalian Intern dan Lingkup Audit Terhadap Kinerja Akuntan Publik di Era Otonomi Daerah (Suatu Studi pada Kantor Akuntan Publik di Kota Palembang). Tesis Program Pascasarjana BKU Ilmu Ekonomi dan Akuntansi Universitas Padjajaran, Bandung.

Jalaluddin Rakhmat. 2008. Metode Penelitian Komunikasi. CV. Remadja karya, Bandung 
James H. Davis , F. David Scoorman dan Lex Donalson, 1997, “Toward a Stewardship Theory of Management, " Accounting of Management Review Volume 22, No. 1 Page 22-47.

John, W. Dischant and Kevin A. Mc. Cabe, 1997, "The Behavioral Foundations of Stewardship Accounting and a Proposed Program of Resarcah: What is Accountability?" Behavioral Research in Accounting. Volume 9

Konsorsium Organisasi Profesi Audit Intern, 2004, "Standar Profesi Audit Intern", Yayasan Pendidikan Intern Audit, Jakarta.

M. Iqbal Hasan. 2009. Pokok-Pokok Materi Statistik 2. Bumi Aksara, Raja Grafindo Persada, Jakarta.

Mahmudi. 2008.. Analisa Laporan Keuangan Daerah : Panduan Bagi Eksekutif DPRD, dan Masyarakat dalam Pengambilan Keputusan Ekonomi, sosial, dan politik, UPP STIM YKPN.

Mardiasmo. 2006. Perwujudan trnasparansi dan akuntabilitas public melalui akuntansi sector public : suatu sarana good governance, jurnal akuntansi pemerintah, vol. 2 No. 1, hal. 1-17.

Mifta Thoha. 2010. Perspektif Perilaku Birokrasi, Dimensi-Dimensi Prima Ilmu Administrasi Negara Jilid II, PT. Raja Grafindo Persada, Jakarta.

Mulyadi.2008."Akuntansi Manajemen (Konsep, Manfaat dan Rekayasa)”. Sekolah Tinggi Ilmu Ekonomi YKPN, Yogyakarta

Noggi, Hassel, 2009 Management Sumber Daya Manusia Birokrasi Publik, YPAPI, Yogyakarta.

Priyanto, Dwi, 2011, “ Mandiri Belajar SPSS”. Cetakan Ketiga. Penerbit PT. Buku Kita. Jakarta

Rahmani, Nani, 2012, “Sistem Pengendalian Intern Pemerintah”Balai Diklat Keuangan, Medan

Rajan, C.A R. Sounders, 2006, "Corporate Governance and Intern Control”, The Cartered Accountant, November 2006.

Sagir. 2008. Ekonomi Indonesia Menghadapi Pelita IV. Alumni, Bandung.

Sawyer, B Lawrens, 2005, "Pemeriksaan Intern", Pusat Pengembangan Akuntansi, Jakarta

Soekidjo Notoatmojo. 2009. Pendidikan dan Pelatihan, Penerbit FKM-UI, Jakarta.

Sondang P Siagian. 2012. Managemen Sumber Daya Manusia, Bumi Aksara, Jakarta.

Sugiyono, 2010. "Metode Penelitian Bisnis". CV. Alfabeta. Bandung.

Sumarni dan wahyuni. 2008. Metodelogi Penelitian Bisnis. CV ANDI, Yogyakarta. 
Wahana Komputer. 2008. Panduan Aplikasi Sistem Akuntansi Online Bebasis Komputer. Penerbit ANDI, Yogyakarta

Wilkepedia Indonesia, 2013. "Opini BPK Atas Audit Laporan Keuangan Pemerintah Daerah BPK”, WWW. Google. Co.Id, Diakses 14 November 2014. , Undang-Undang Nomor 17 Tahun 2003 tentang Keuangan Negara. , Undang-Undang Nomor 1 Tahun 2004 tentang Perbendaharaan Negara , Peraturan Menteri Dalam Negeri Nomor 13 Tahun 2006 tentang Pedoman Pengelolaan Keuangan Daerah. , Peraturan Pemerintah Nomor 24 Tahun 2009 tentang Standar Akuntansi Pemerintahan. , Peraturan Pemerintah Nomor 60 Tahun 2008 tentang Sistem Pengendalian Intern Pemerintah , Peraturan Daerah Nomor 10 Tahun 2008 tentang Susunan Organisasi Pemerintah Daerah Kota Palembang

Peraturan Daerah Nomor 8 Tahun 2007 tentang Struktur Organisasi Kabupaten Musi Banyuasin 